[American Journal of Science, Vol. 304, September, 2004, P. 590-611]

\title{
FORM OF SUBMARINE EROSION FROM CONFLUENCES IN ATLANTIC USA CONTINENTAL SLOPE CANYONS
}

\author{
NEIL C. MITCHELL \\ School of Earth, Ocean and Planetary Sciences, Cardiff University, P. O. Box 914, \\ Cardiff CF10 3YE, Wales, United Kingdom; neil@ocean.cardiff.ac.uk
}

\begin{abstract}
Submarine canyons of the Atlantic continental slope are found to have some remarkably analogous morphological properties to river networks, such as inverse power-law relations between channel gradient $S$ and contributing area $A(S \sim$ $\left.A^{-\theta}\right)$. Such relationships for bedrock-incising rivers have been interpreted using models in which bed erosion rates $(\dot{E})$ depend on $A$ and $S$ according to $\dot{E} \sim \mathbf{A}^{\mathbf{m}} \mathbf{S}^{\mathbf{n}}$, where the $A^{m}$ term represents the effect of discharge increasing down-stream. For areas of spatially balanced erosion, the model predicts the inverse relation $S \sim A^{-\theta}$. It is argued here that erosion of canyon floors by turbidity currents involves similar processes to river bed erosion so that a similar model could be used to help interpret aspects of canyon morphology and differences between canyon systems. Discharge and flow power, however, do not vary down-stream in submarine canyons in the same way as in fluvial networks because tributaries are not usually active simultaneously. As turbidity currents and other sedimentary flows originate from failure of oversteepened deposits in canyon walls, the frequency of erosive flows experienced by the channel increases with $\mathrm{A}$. This process produces a down-stream erosive effect analogous to that of discharge in river networks. The model's applicability is explored here by comparing the ratio of gradients and areas at confluences where erosion rates of the converging branches must be equal (Seidl and Dietrich, 1992). The data show significant scatter due to canyon floor irregularities, but they suggest on average $m / n=0.2-0.3$ if $\dot{E} \sim \mathrm{A}^{\mathrm{m}} \mathrm{S}^{\mathrm{n}}$. Gradient-area graphs of canyons heading at the shelf break and of those heading within the slope are identical. Therefore, although the classical sequence stratigraphic model predicts that shelf spillover during glacial lowstands is important for incising continental slopes, there is little evidence that shelf spillages occurred by direct supply of sediment to canyon heads, as this supply would have modified the slopes gradient-area relationships differently.
\end{abstract}

\section{INTRODUCTION}

A major aim of subaerial geomorphology is to understand quantitatively how runoff and other agents erode the earth's surface, in order that climatic and tectonic effects can be interpreted from landscapes and from the sedimentary products of erosion (Burbank and Anderson, 2000). The new sonar datasets becoming available (Pratson and Haxby, 1997) now prompt the question of whether a comparable effort would be possible in marine geology. In particular, as physically based models for the dynamics of sedimentary flows become more realistic, it would be desirable to predict, not just how they individually affect their substrates, but how their cumulative effect creates the eroded morphology of submarine slopes. Conversely, such modeling may help in determining whether some aspects of erosion by sedimentary flows can be interpreted from large-scale morphology.

Turbidity currents (sedimentary flows in which suspended sediment loads are maintained by fluid turbulence (Bagnold, 1963) are often regarded as the submarine equivalents of rivers in eroding slope canyons (Daly, 1936), and submarine canyon systems can indeed appear visually similar to their subaerial counterparts (McGregor and others, 1982; Pratson and Ryan, 1996). In both turbidity currents and rivers, the driving force is gravity acting on a body of water of anomalous density compared with its ambient fluid. Erosion of river beds occurs by plucking or quarrying of coarse material and abrasion by particles within the flow, with the former being more important in beds of fissile materials (Hancock and others, 1998; Whipple and others, 
2000). As smooth abraded surfaces and quarried blocks are also observed in submarine canyon floors and walls (Shepard and others, 1964; McHugh and others, 1993), it is suggested here that the same physical processes are involved in canyon erosion by turbidity currents and by debris flows (denser flows with particles supported by a sedimentary matrix rather than turbulence).

A companion study of longitudinal profiles (Mitchell, unpublished data) documents the gradient-area graphs of individual slope canyons. It shows that the relation $\mathrm{S} \sim \mathrm{A}^{-\theta}$ is common in the USA Atlantic slope and occurs with a similar range of graph power-law gradients $\theta$ to rivers (where $\theta$ is otherwise called channel 'concavity'). To explain such graphs, a model is developed for the erosive effect of turbidity currents in which the frequency of flows experienced by the canyon floor increases down-canyon and with increasing contributing area, representing the up-stream area of canyon walls with potentially unstable sediment capable of sourcing erosive sedimentary flows. A similar effect of contributing area has also been suggested to describe erosion of colluvial valleys by debris flows (Seidl and Dietrich, 1992). Although rivers tend to flow continually, whereas submarine channels are active only occasionally during sedimentary flow events, this distinction is not considered important here because in practice erosion in subaerial bedrock channels also occurs episodically with extremes of river discharge (Snyder and others, 2003).

Erosion by turbidity currents and rivers are, however, likely to differ in a number of respects. The density contrast of the flow with the ambient fluid is less for a turbidity current than it is for a river current and thus changes in the solid load have a greater effect on flow power and erosive potential in underwater systems, leading to feedback effects between flow power and bed erosion (Parker and others, 1986). Continental slope turbidity currents usually have much greater thicknesses than rivers (Piper and others, 1988), incorporate ambient water and experience friction with the overlying fluid (Komar, 1977). The effects of some of these differences are revealed by geometrical differences between meandering river and turbidity current channel deposits (Peakall and others, 2000). Debris flows may also behave differently in submarine environments owing to their potential to hydroplane over the seafloor. According to Harbitz and others (2003) hydroplaning can lead to a dramatic reduction in the flow bed shear stress and can reduce the flow's potential to erode substrates.

The following study was motivated by the observation of Seidl and Dietrich (1992) that long-term erosion rates of two branches of a river confluence must be identical because tributary channels tend to approach their associated principal channels at the same elevation (Playfair, 1802), without an intervening waterfall. This observation implies that tributary channels adjust by erosion to changes in elevation of the principal channel, and is also a feature of the submarine tributaries described here. Seidl and Dietrich (1992) argued that the contrast in channel gradient (S) and contributing area (A) measured at confluences can be used to test conformance to an erosion law based on $\mathrm{S}$ and $\mathrm{A}$, and to recover the ratio of the power-law exponents if that law that is applicable. In subaerial fluvial systems, the method essentially quantifies the observation that a tributary typically enters a principal channel with a steeper gradient because it drains a smaller area and has less powerful discharge.

The text below shows how a stream-power erosion law can be constructed for submarine erosion. It is stressed that the details of flow process and bed erosion are more uncertain in submarine settings, reflecting the more limited observations of process available, and thus the model is less rigorous than its subaerial counterpart. Nevertheless, it should be useful for providing a basis for discussing the origin of morphologic differences between different submarine canyon systems. Differences of canyon long-profile concavity, for example, can be related to spatial variations in sediment input, triggers of slope failure or substrate resistance to erosion. To avoid 


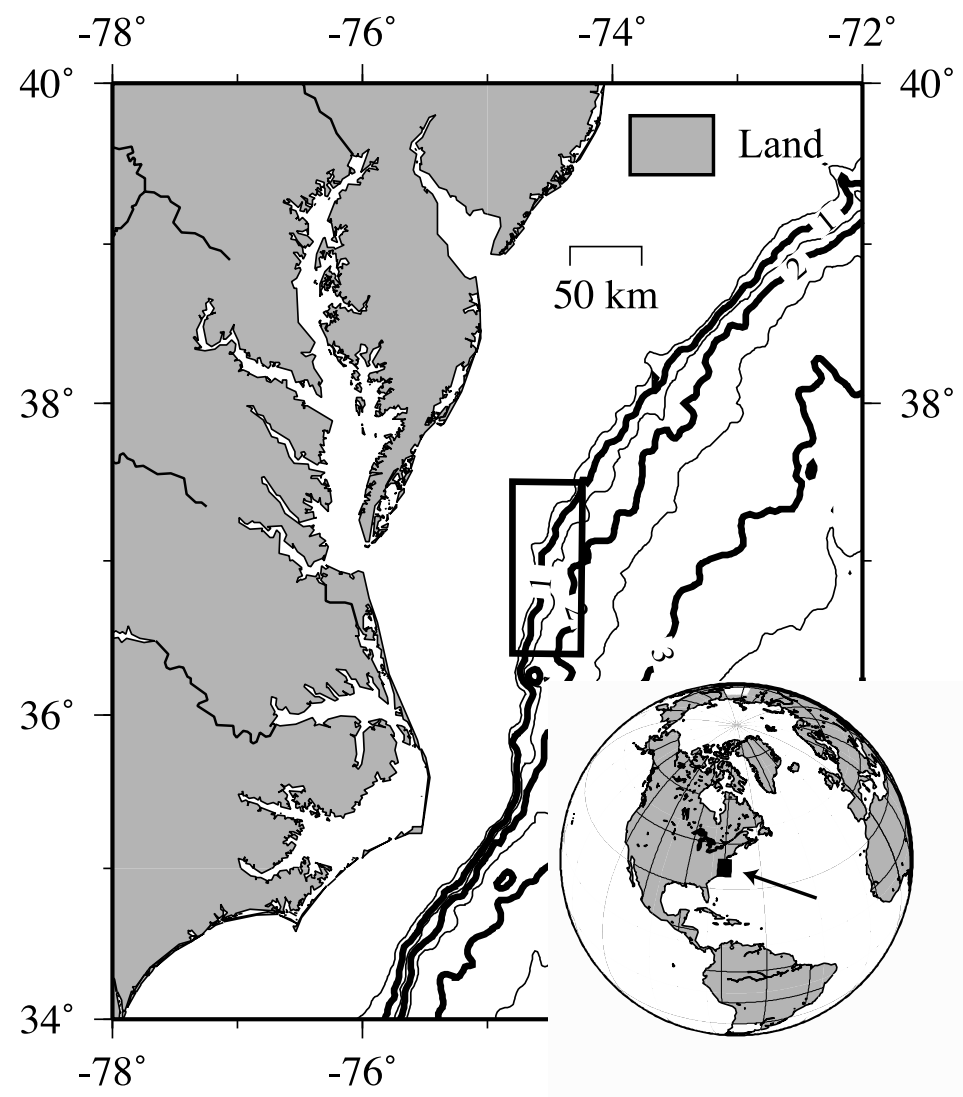

Fig. 1. Location of the multibeam echo-sounder data shown in figure 2. Bathymetry contours are shown every $500 \mathrm{~m}$ with bold contours annotated every $1 \mathrm{~km}$.

confusion, the term "slope" is restricted to the geomorphological feature whereas "gradient" is used for the rate of elevation change.

\section{BACKGROUND TO THE CONTINENTAL SLOPE GEOLOGY}

The continental slope of the central Atlantic USA margin shown in figures 1 and 2 has erosional relief produced in the late Tertiary (Schlee and others, 1979). Surface sediments on the slope are silty clays or clayey silts and sedimentation is presently from hemipelagic fallout rather than from sands originating from the shelf (Doyle and others, 1979; McGregor and others, 1979). Such shelf sand "spillover" is probably in general rare on the open continental slope because boreholes from 11 legs of the Ocean Drilling Program (ODP) and Deep Sea Drilling Project sited on the slope in various margins of the world have recovered mainly pelagic and hemipelagic sediments (Pratson, 2001). Whereas the classical sequence stratigraphic model (Vail and others, 1977) implies that sediment transport off the shelf and associated canyon erosion occurs during glacial lowstands by remobilization of shelf sediments, some recent attempts to verify the model in modern continental slopes have produced contradictory results. The incidence of gravity flow deposits in New Jersey slope ODP Leg 150 sites, for example, only weakly correlates with the Last Glacial Maximum and deposition rates show no correlation (McHugh and others, 2002; McHugh and Olson, 
A

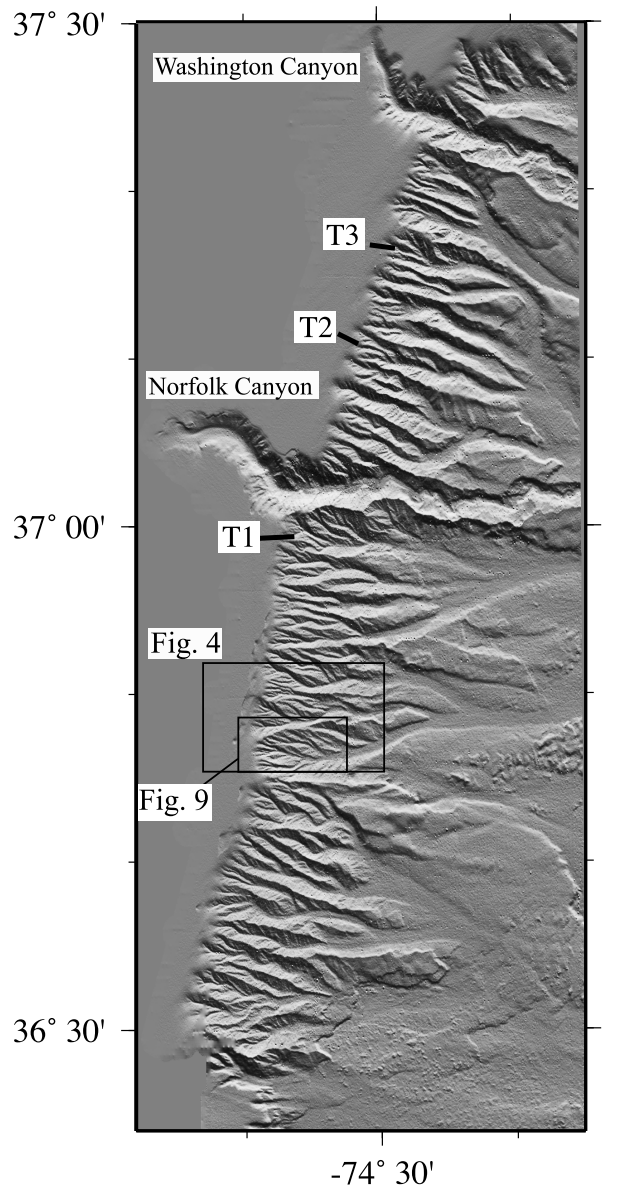

B

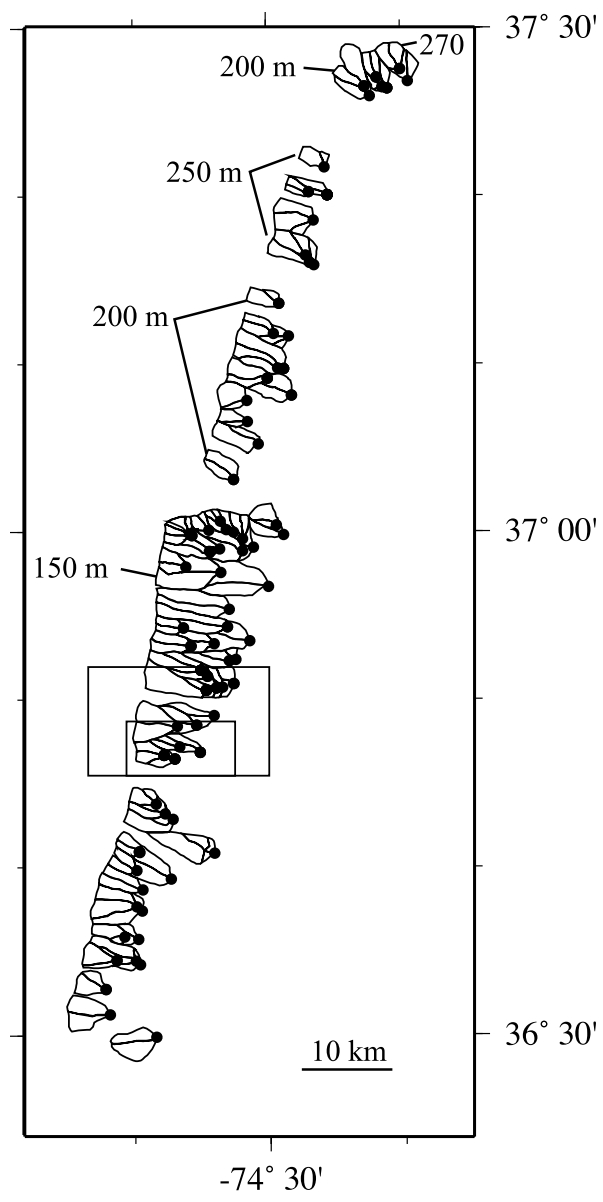

Fig. 2. (A) Shaded-relief image of bathymetry of the USA Atlantic continental slope off Virginia state showing canyons incising the slope. The data were collected with multibeam echo-sounders of National Ocean Service survey ships Whiting and Mt Mitchell and made available by the National Geophysical Data Center (Coastal Relief Model). The map location is marked in figure 1. The data are plotted in a Universal Transverse Mercator projection. Two major shelf-incising canyons, Norfolk and Washington, are marked, as well as three canyons with tributaries (T1-T3). (B) The map to the right shows interpreted hemipelagic catchment areas of canyons. The numbers shown are the depths of contours used to define canyon heads. Solid circles mark channel confluences.

2002). Peak deposition rates on the slope in a Southern California study occurred during sea level transgression, not lowstand as might be expected (Sommerfield and Lee, 2004). No particular timing of the erosion is therefore assumed here.

The following studies of the central and northern Atlantic USA continental rise documented deposits of debris flows and slides, showing that they, as well as turbidity currents, are likely involved in erosion of the slope above. Interpretation of $3.5 \mathrm{kHz}$ profiler records of the upper rise below the area in figure 2 (Pratson and Laine, 1989) revealed irregular deposits of debris flows and slides forming channels emanating away from Norfolk and Washington canyons, and also from some intermediate canyons. Low-frequency long-range sidescan sonar is capable of penetrating to a few meters within sediment so it can detect buried surfaces (Mitchell, 1993); such data of the 
upper rise also reveal some high-backscatter ribbons appearing to emanate from canyons, some of which have been verified by coring as elongated debris flow deposits (EEZ Scan, 1991; Schlee and Robb, 1991; McHugh and others, 2002).

Seismic reflection data collected parallel to the margin show that the canyons have incised a pre-existing stratigraphy (McGregor and others, 1979; Forde, 1981). However, higher resolution seismic data from the New Jersey slope (Farre, 1987; Pratson and others, 1994), near Wilmington Canyon (McGregor and Bennett, 1977) and from the slope $50 \mathrm{~km}$ northeast of Washington Canyon (McGregor and others, 1979) show that stratigraphy within the upper canyon walls in detail commonly dips towards the channels rather than being sharply truncated at the seafloor. This dip implies that some of the canyon topography has developed by aggradation of the interfluves (inter-canyon divides) relative to their adjacent canyon floors. This aggradation arises because enhanced oceanographic currents in canyons (Shepard, 1981; Cacchione and others, 2002), as well as the sedimentary flows considered here, cause reduced or non-deposition along channels relative to interfluves. Development of the canyon relief therefore involves removal of buried, consolidated stratigraphy and the less indurated material that would otherwise build the slope (hemipelagic fallout occurring between erosive flow events).

The data studied (figs. 1 and 2) are multibeam echo-sounder data collected by the US National Ocean Service (NOS) and made available by the National Geophysical Data Centre in gridded form (Coastal Relief Model). The area includes two major shelf-incising canyons, Norfolk and Washington, but mostly a series of canyons restricted to the slope. Water depths vary from the shelf $(<150 \mathrm{~m})$ to more than $2000 \mathrm{~m}$.

\section{EROSION MODEL}

In detachment-limited fluvial erosion models, the rate at which bedrock channels incise is related to either bed shear stress due to the flow (Howard, 1994) or to the specific stream power [flow power per unit width of stream (Hancock and others, 1998)]. Both approaches have been shown to imply an erosion law of the form $\dot{E}=\mathrm{k}_{\mathrm{f}} \mathrm{A}^{\mathrm{m}} \mathrm{S}^{\mathrm{n}}$. Applying the shear stress approach to erosion by submarine turbidity currents, the model erosion rate $\dot{E}$ is postulated locally to follow $\dot{E} \sim \tau^{\text {n }}$ where $\tau$, bed shear stress due to the flow, is proportional to the square of depth-averaged flow speed $\mathrm{U}^{2}$. The exponent $\mathrm{n}$ is not necessarily spatially and temporally constant as the channel could erode different lithologies with different primary detachment mechanisms (Hancock and others, 1998). Using a Chezy-type formula for flow speed (Komar, 1969), the erosion rate during passage of an individual turbidity current would then follow:

$$
\dot{E} \sim\left(\frac{8 \mathrm{~g}^{\prime} \mathrm{hS}}{\left(\mathrm{f}_{0}+\mathrm{f}_{\mathrm{i}}\right)}\right)^{\mathrm{n}}
$$

where $\mathrm{h}$ is the flow thickness $(\mathrm{m})$ and $\mathrm{g}^{\prime}$ represents the depth-averaged specific weight of the flow equal to $\mathrm{g} \Delta \rho / \rho$ ( $\mathrm{g}$ is the acceleration due to gravity $\left(\mathrm{m} / \mathrm{s}^{2}\right), \rho$ is the flow's density $\left(\mathrm{kg} / \mathrm{m}^{3}\right)$, and $\Delta \rho$ is the flow excess density relative to the ambient water $\left(\mathrm{kg} / \mathrm{m}^{3}\right)$. The symbols $\mathrm{f}_{\mathrm{o}}$ and $\mathrm{f}_{\mathrm{i}}$ are the Darcy-Weisbach friction factors of the flow's base and overlying water column, respectively. Erosion in subaerial channels is known also to depend on other factors such as degree of weathering between erosive flows (Howard, 1998). The type and concentration of sediment loads are important, with no tools available for abrasion if there is no sediment load and heavy sediment load causing armoring of the bed (Sklar and Dietrich, 1998; Sklar and Dietrich, 2001). These factors will also likely complicate submarine erosion by sedimentary flows, so equation (1) is an idealized representation of erosion. 


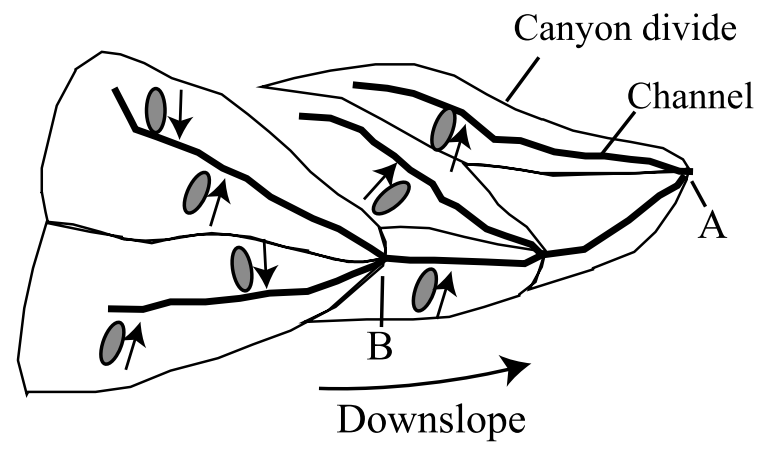

Fig. 3. An effect expected to cause increasing erosion rate with contributing area A can arise because the frequency and maximum size of sedimentary flows initiated by slope failures increase down-channel. The figure illustrates this with seven slope failures in canyon wall gullies (gray ellipses). Thus below confluence 'A' the effect of all seven flows are experienced whereas immediately below 'B' only four flows are experienced.

The time-averaged erosion rate caused by the passage of many flows can be related to channel contributing area A using a similar mechanism to that proposed by Seidl and Dietrich (1992) for erosion of subaerial colluvial valley channels (channels above river headwaters). Here, the time-averaged erosion rate depends on the frequency at which flows travel down-channel, which in turn depends on the area of upstream canyon walls with potentially unstable sedimentary deposits (fig. 3).

In this model, the flow frequency reflects the volume flux of hemipelagic material to the upstream canyon. In other words, the more rapidly hemipelagic material is accumulating in a part of a canyon, the faster the canyon walls will over-steepen relative to the canyon floor and the more likely a slope failure will occur there leading to a sedimentary flow, other factors being equal. Spatially varied sediment input will lead to spatially varied erosion analogous to that caused by varied precipitation in river networks (Roe and others, 2002). Slope failures could also be promoted in restricted parts of the slope by fluid escape from underlying strata (Dugan and Flemings, 2000; Dugan and others, 2003). These effects should be considered in a more thorough analysis but, as this study involves comparing immediately adjacent canyon branches, they are minimized to some degree.

If seismicity triggers widespread slope failure causing multiple sedimentary flows, it is possible for several adjacent channels to be simultaneously active (Piper and others, 1988, 1999; Adams, 1990; Goldfinger and others, 2003). Such a situation could lead to flow power increasing past tributary confluences in a manner analogous to fluvial systems if the combination of flow geometry and durations allowed flows to merge at confluences. How frequently this situation occurs is unclear as flow synchroneity is difficult to prove, but the effect could be interesting if converging simultaneous flows lead to a different tendency for $\dot{E}$ to increase with A (hence different exponent 'm'). The tendency for $\dot{E}$ to increase with A might be tested by seeing if tectonically active areas have a measurably different eroded morphology to passive margin slopes.

Incorporating canyon area $A\left(\mathrm{~m}^{2}\right)$ and replacing $G=g^{\prime} h /\left(f_{o}+f_{i}\right)$ in equation (1), the time-averaged erosion rate caused by many flows is proposed to vary according to:

$$
\dot{E}=\mathrm{KA}^{\mathrm{m}} \mathrm{G}^{\mathrm{n}} \mathrm{S}^{\mathrm{n}}
$$

An exponent $\mathrm{m}$ is applied to A because the above effects of flow convergence and frequency down-network are likely to lead to an imperfectly linear effect of A. The fact that sedimentary flow deposits have been found on the continental slope by drilling 
(McHugh and others, 2002) and geophysical imaging (Piper and others, 1999) suggests that sedimentary flows do not always fully run-out, hence producing a tendency for $\mathrm{m}<1$. The parameter $\mathrm{K}$ represents bedrock erodibility and erosive potential of the flows (such as owing to the tools carried by them) much like with river bed erosion (Whipple and Tucker, 2002). It also represents the timescale of erosion imposed by the rate at which hemipelagic sediment accumulates in canyon walls or other cause of erosive flows and is not necessarily temporally or spatially constant.

Flow widening down-stream will also affect bed shear stress and hence the exponent ' $m$ ' as with rivers (Montgomery and Gran, 2001). It is difficult to quantify because the inner channel is poorly resolved in these multibeam data. Higherresolution sidescan and multibeam sonar data of steep upper continental slopes (Alonso and others, 1985; Malinverno and others, 1988; Goff and others, 1999; Klaucke and Cochonat, 1999) typically show that the channels are narrow and usually close to sonar resolution, or, where the channel floor is resolved, farther down the continental slope, it is then unclear if it represents a modern surface of channel fill deposits post-dating the erosion. The author is unaware of sediment profiler or seismic data capable addressing this issue adequately at present.

As the following investigates relations among the measurable parameters $\mathrm{S}$ and $\mathrm{A}$, the analysis requires that variations in $G$ be comparatively small. As flows pass down-canyon, however, G could vary because flows incorporate bed material, inflate by incorporating ambient water or change thickness and width with changes in velocity, gradient and width of the constraining channel, or they may deposit with declining channel gradient. Some of these effects are partially compensating, for example incorporation of ambient water will decrease $\mathrm{g}^{\prime}$ but increase $\mathrm{h}$, thus leading to a small change in $\mathrm{G}$. However, some systematic variation in $\mathrm{G}$ is likely to occur down-stream on average and will be in part correlated with $\mathrm{A}$, affecting the apparent ratio of exponents $\mathrm{m} / \mathrm{n}$ recovered by the analysis.

An equation similar to (2) could also be derived for erosive effects of debris flows. If a debris flow's velocity is steady and slow, the shear stress at the base of the flow must balance its weight so it is simply $\left(\rho_{\mathrm{df}}-\rho_{\mathrm{w}}\right)$ ghS where $\rho_{\mathrm{df}}$ and $\rho_{\mathrm{w}}$ are, respectively, the depth-averaged debris flow and ambient water densities $\left(\mathrm{kg} / \mathrm{m}^{3}\right)$. However, as debris flows have the potential to hydroplane and decouple from the seabed (Harbitz and others, 2003), their erosive effects are unclear. Indeed, a lack of coupling between debris flow and substrate may explain why erosive relief is relatively subdued in slopes developed in front of ice streams where debris flows are common (Dowdeswell and others, 2002), such as the Hebrides Slope (Armishaw and others, 2000) and Marquerite Bay, Antarctica (Dowdeswell and others, 2004).

CALCULATION OF GRADIENT-AREA STATISTICS

Enlarged maps of contoured bathymetry and shaded relief images were produced from the gridded data supplied by NOAA using open-source software (Wessel and Smith, 1991) at a scale of 1:58000 so that the hemipelagic catchment areas of canyons and their confluences could be recorded as illustrated in figure 4. Catchment boundaries were readily located and mapped out along the sharp interfluves between canyons. The canyons were classified into those with upstream tributary canyons that head at the shelf break and those that head solely within the continental slope. The latter mostly have other canyons separating them from the shelf edge. For those canyons that terminate at the shelf break, the catchment was difficult to map because the limit of the canyon can be poorly defined morphologically. For consistency, a contour was interpreted as the upslope limit of these canyons, which was principally the $150 \mathrm{~m}$ depth contour, but the 200 and $250 \mathrm{~m}$ contours were more effective delimiters in the north of the area (fig. 2B and 4). The estimated average uncertainty in A arising from poor definition of the shelf break is $0.7 \mathrm{~km}^{2}$. The full set of catchment 


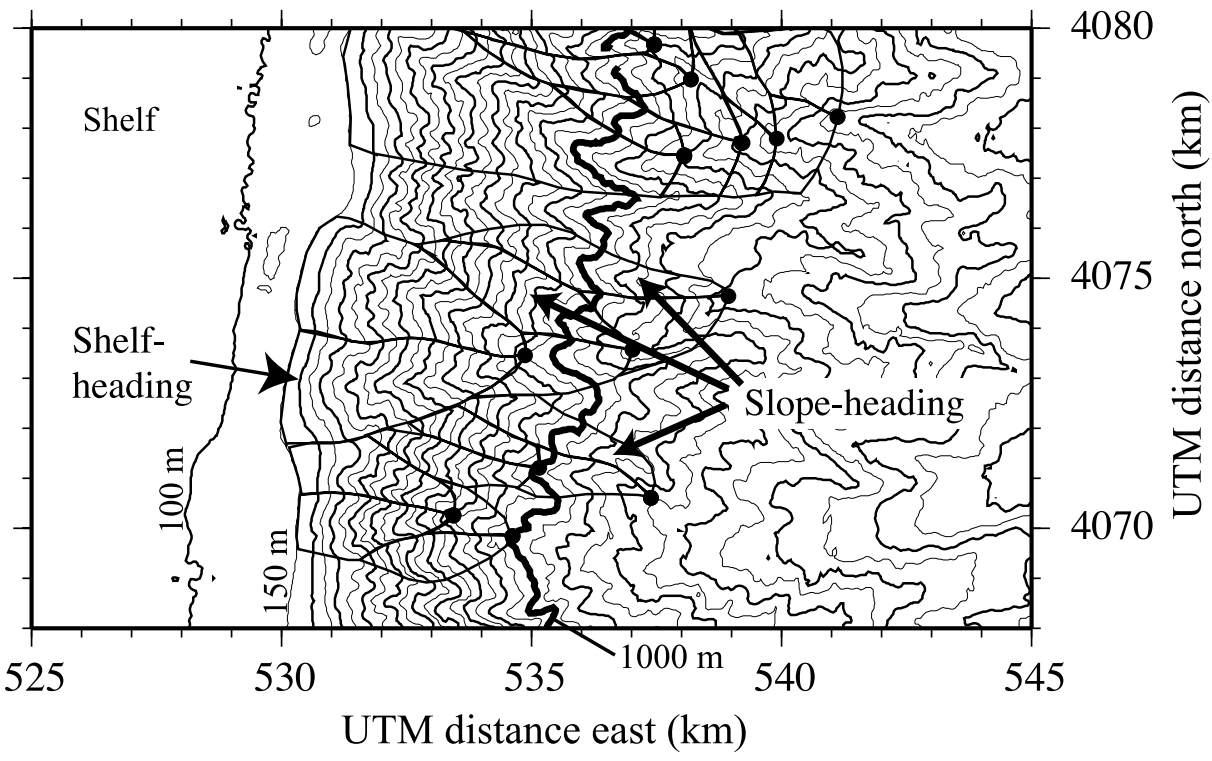

Fig. 4. Detail of the bathymetry in figure 2. Depth contours are shown every $50 \mathrm{~m}$ with intermediate bold every $100 \mathrm{~m}$ and strong bold every $1000 \mathrm{~m}$ (contour marked). Bold circles mark the canyon confluences. Coordinates are Universal Transverse Mercator projection distances in kilometers (UTM zone 18, projection calculated with the WGS84 ellipsoid). Examples of canyons classified as slope-heading and shelf-heading are shown. Canyon areas of the latter are limited shoreward by the shelf break, here defined by the $150 \mathrm{~m}$ contour.

area data is shown in figure 2B. Each network includes between 1 and 11 interpreted confluences. The calculated upstream areas are shown in figure 5. The uncertainties shown in figure 5 were calculated by combining the accuracy of defining catchments laterally (along the slope) with the above-mentioned uncertainty in delimiting the canyon heads. As the latter is the largest uncertainty, the uncertainties are larger in figure 5A than for those canyons isolated from the shelf break in figure 5B.

Channel gradients were measured from the contoured bathymetry maps. For each channel, this was carried out by measuring the along-channel separation of two contours representing a $100 \mathrm{~m}$ depth change. Measurements were made immediately upslope of the confluences marked by the bold circles in figures 2 and 4 . Based on the apparently artificial irregularity of bathymetry contours in areas of flat terrain, it was estimated that vertical accuracy of the gridded data was typically $5 \mathrm{~m}$. The effect of this uncertainty on the gradient values was combined with an estimate of the ruler uncertainty used in measuring the contour separations to produce the uncertainties in gradient $\mathrm{S}$ shown in figure 5 . Because the channel profiles are curved and gradient was measured over a finite distance, the measured gradients will be slightly biased on average. However, simulations in Niemann and others (2001) of subaerial landscapes calculated with similar $\mathrm{m} / \mathrm{n}$ suggest that the error is only 10 percent when gradient is measured with a ruler length of 10 percent of the full channel length, as is typical for these canyons. The effect of this bias will also be reduced somewhat as the analysis involves changes in gradient and gradient ratios rather than absolute values.

RESULTS

Figure $5 \mathrm{~A}$ reveals a relatively simple trend of $\mathrm{S}$ gradually declining on average with increasing $\mathrm{A}(\mathrm{R}=0.67)$. Interestingly, the data in figure $5 \mathrm{~B}$ for canyons isolated from 


\section{A. Canyons heading at the shelf break}

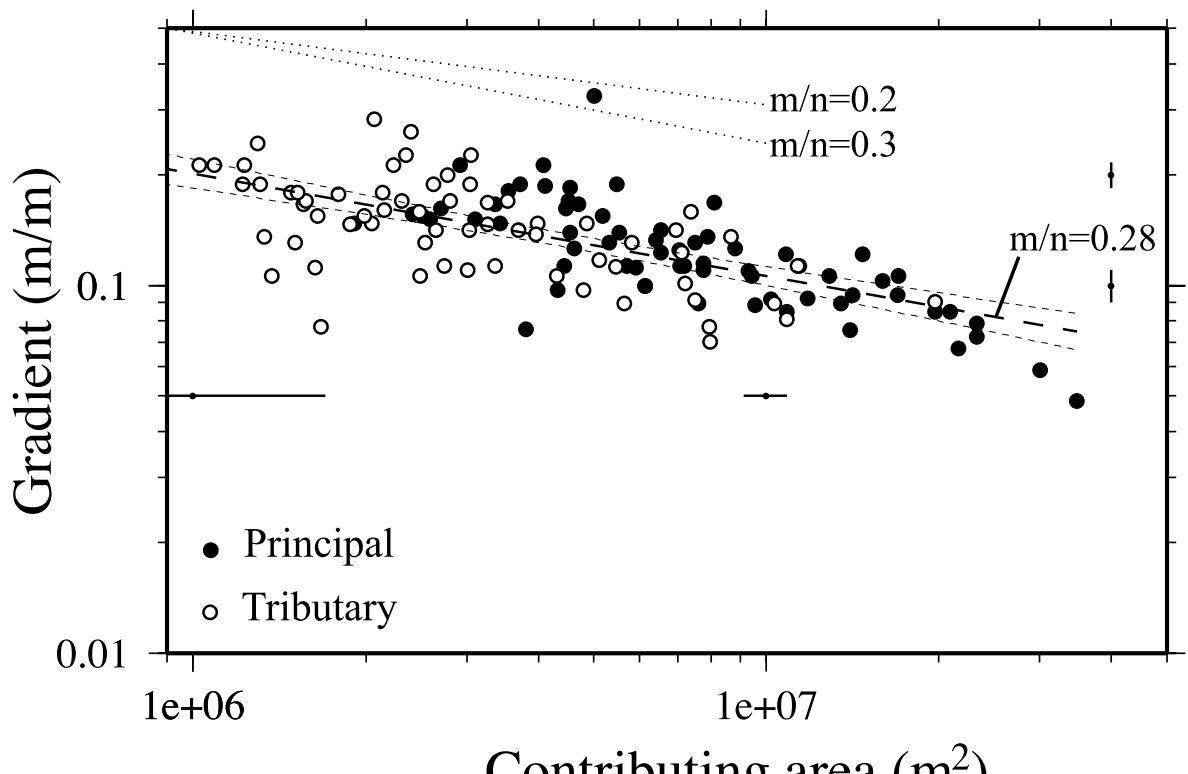

B. Canyons heading within the continental slope

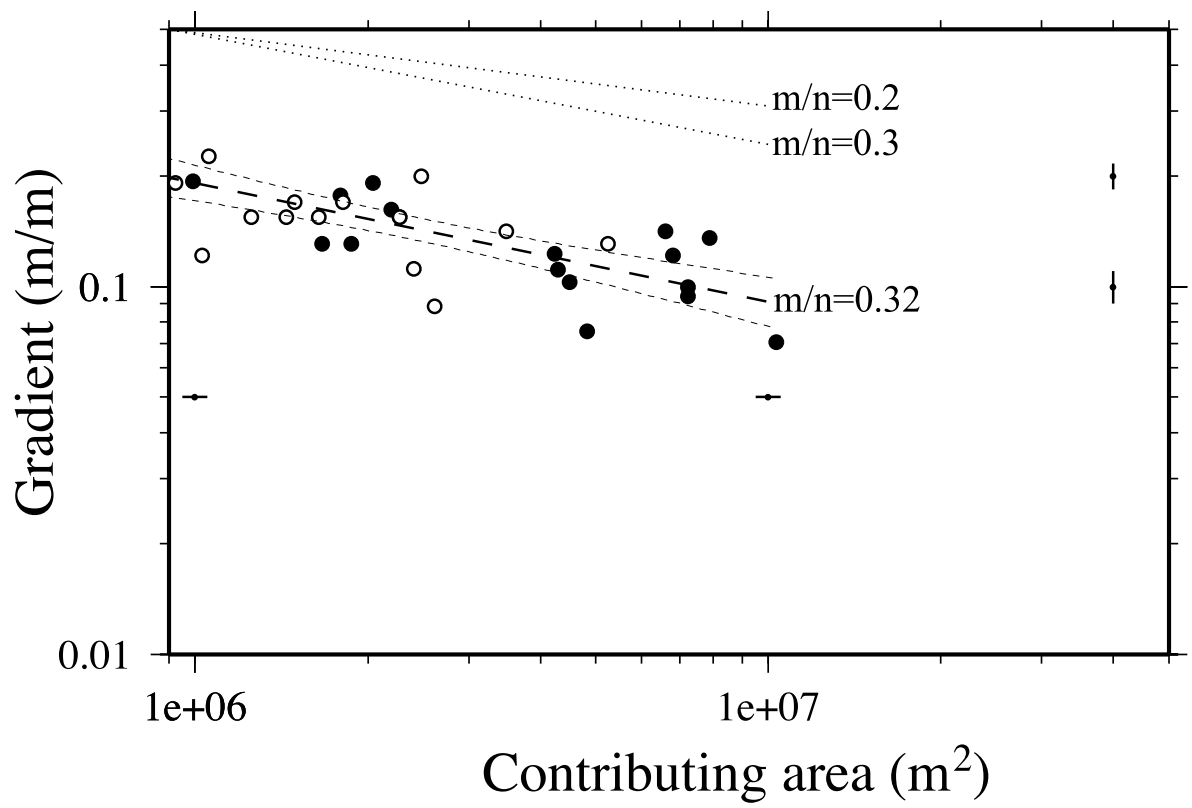

Fig. 5. Graphs of the channel gradient and hemipelagic catchment area for (A) canyons that extend from the shelf break and (B) canyons not linked to the shelf but heading within the continental slope. Gradient immediately up-slope of channel confluences was derived by measuring the spacing of $100 \mathrm{~m}$ depth contours. Contributing areas were measured up-slope from the confluences. The principal and tributary channels are shown by solid and open circles, respectively. See text for derivation of uncertainties shown by the error bars. The bold dashed lines are least-squares regressions of $\log _{10} \mathrm{~S}$ on $\log _{10} \mathrm{~A}$ with graph slopes of (A) $\mathrm{m} / \mathrm{n}=0.28 \pm 0.05$ and $(\mathrm{B}) \mathrm{m} / \mathrm{n}=0.32 \pm 0.10( \pm 2 \sigma)$ and the encompassing fine dashed lines are their $95 \%$ confidence intervals in the predicted $\log _{10} \mathrm{~S}$. The dotted lines show the graph slope expected from a steady state model with the concavity values shown. 
the shelf break are no different to those in figure 5A. If erosion of the slope canyons were strongly influenced by sedimentary flows initiated near the shelf break from shelf sediment, we might expect a difference between those canyons that head at the shelf break compared with those that head within the slope and are isolated from the shelf. Sedimentary flows at the canyon heads would have led to deeper incision there compared with the heads of the isolated canyons, and hence different S-A relationships should have emerged. (The regression line in figure 5A does lie slightly to the right of that in figure $5 \mathrm{~B}$, but the offset is statistically insignificant.) This is consistent with most continental slope sediment being hemipelagic not sandy (Pratson, 2001) and with most erosion activity from sedimentary flows and mass-movements having developed within the slope (Pratson and Coakley, 1996). This issue is addressed again in the discussion.

The data were analyzed following the method of Seidl and Dietrich (1992). From equation (2), if the time-averaged $\mathrm{G}$ and durations of flows passing down adjacent confluence branches were the same, the model balance of erosion rates for submarine channels is:

$$
\mathrm{A}_{\mathrm{p}}^{\mathrm{m}} \mathrm{S}_{\mathrm{p}}^{\mathrm{n}}=\mathrm{A}_{\mathrm{t}}^{\mathrm{m}} \mathrm{S}_{\mathrm{t}}^{\mathrm{n}}
$$

where the subscripts refer to the principal $(p)$ and tributary $(t)$ channels. The size of sedimentary flows (solid loads and durations) may well correlate with the upstream area because this dictates the maximum potential size of initiating slope failures and because the amount of channel floor sediment incorporated by a flow likely relates to the length of channel it travels. Assuming equal G and $\mathrm{K}$ between two confluence branches therefore leads to inaccuracies in equation (3) and explains some of the scatter in the following graphs. Some of this variation in erosive potential will be correlated with $\mathrm{A}$ and affect the exponents ratio $\mathrm{m} / \mathrm{n}$ recovered by the analysis

The ratio $\left(A_{p} / A_{t}\right) /\left(S_{t} / S_{p}\right)$ should be constant if the erosion occurs by a common process that follows equation (2) with constant $K, m$ and $n$, equal $G_{t}$ and $G_{p}$, and if the erosive effect of A were as suggested. Seidl and Dietrich (1992) found that this ratio was relatively constant for $S_{t}<0.2$ but strongly varied for $S_{t}>0.2$, a result which they interpreted as due to the data following a fluvial incision law at the lower gradients but, where tributaries are steep $\left(S_{t}>0.2\right)$, those branches erode from the effects of debris flows obeying a different erosion law. The data here (fig. 6) show variability over all $\mathrm{S}_{\mathrm{t}}$. The variability for canyons that do not intersect the shelf edge (fig. 6B) are less varied, which could indicate that they are more reliable for this analysis, although there are also fewer data.

Figure 7 shows the corresponding ratios of gradient and area. If erosion follows equation (3), the data should form a straight line, with a graph slope representing the ratio $\mathrm{m} / \mathrm{n}$ as illustrated by the dotted lines. There is a fair degree of variability in the graphs $(\mathrm{R}=0.36$ and 0.60 for figs. $7 \mathrm{~A}$ and $7 \mathrm{~B}$, respectively). Based on the data uncertainty (bars on the right side of the figure), the variability is not merely an artifact of data precision. Sklar and Dietrich (1998) studied a number of stream junctions in the Noyo River Basin, California and found a much larger variability than in Seidl and Dietrich's (1992) study and also larger than shown in figure 7. They ascribed their data variability to landscape disequilibrium and valley widening in response to relative base level changes. As illustrated by the long-profiles in figure 8, the submarine channels do have knickpoints, which cause some of the variability in gradient. It is unclear if knickpoints here are caused by similar transient effects, because base-level (the continental rise) is static. Transient effects could instead arise from enhanced erosion of a principal channel, leaving the tributary forming a hanging valley but few such examples were found in these data. Most likely, a large part of the variability arises from varied substrate properties such as cohesion and jointing (Miller, 1991) because 


\section{A. Canyons heading at the shelf break}

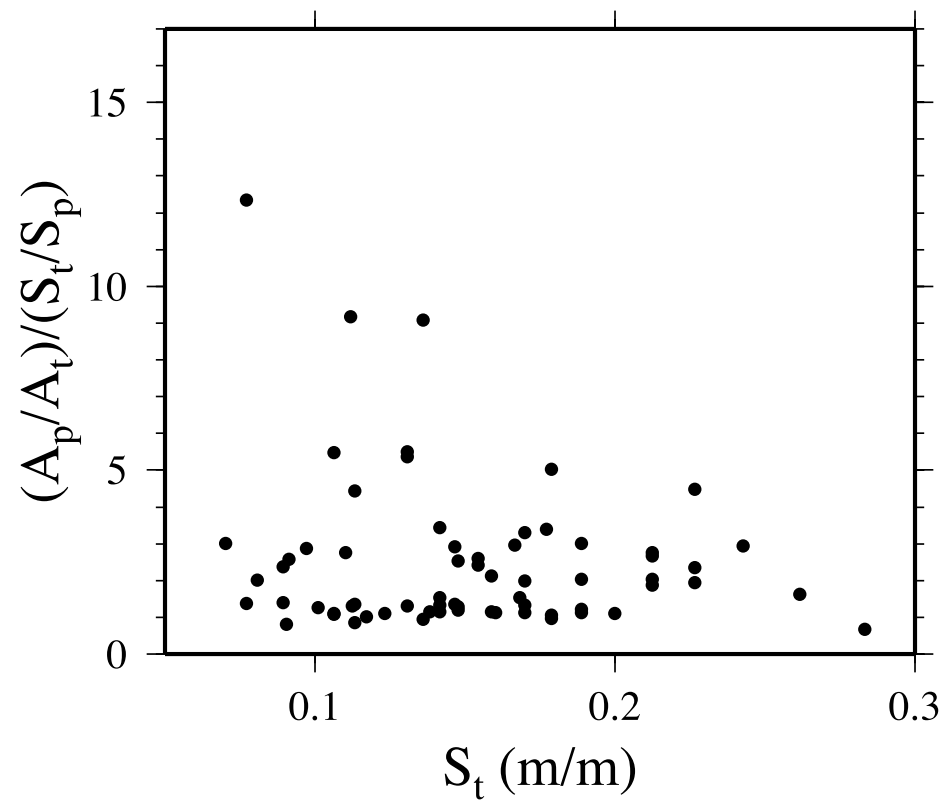

B. Canyons heading within the continental slope

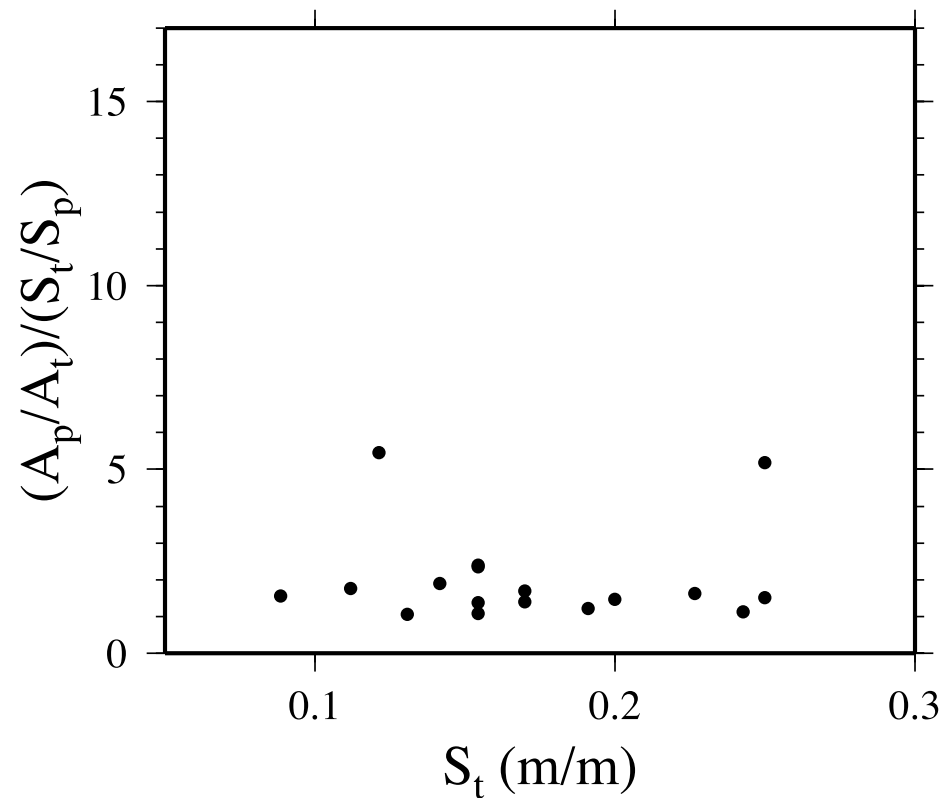

Fig. 6. Ratio of areas and gradients versus the tributary gradient $S_{t}$ for $(A)$ canyons that extend from the shelf break and (B) canyons not linked to the shelf but heading within the continental slope. Note generally less variability in $(\mathrm{B})$ than $(\mathrm{A})$. 


\section{A. Canyons heading at the shelf break}

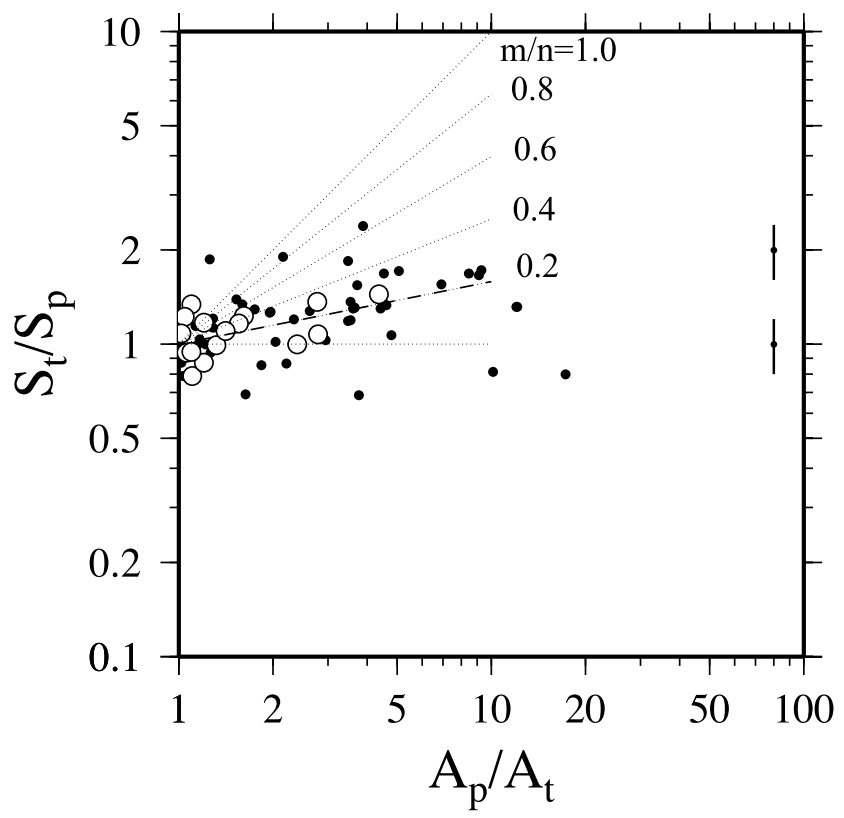

\section{B. Canyons heading within the continental slope}

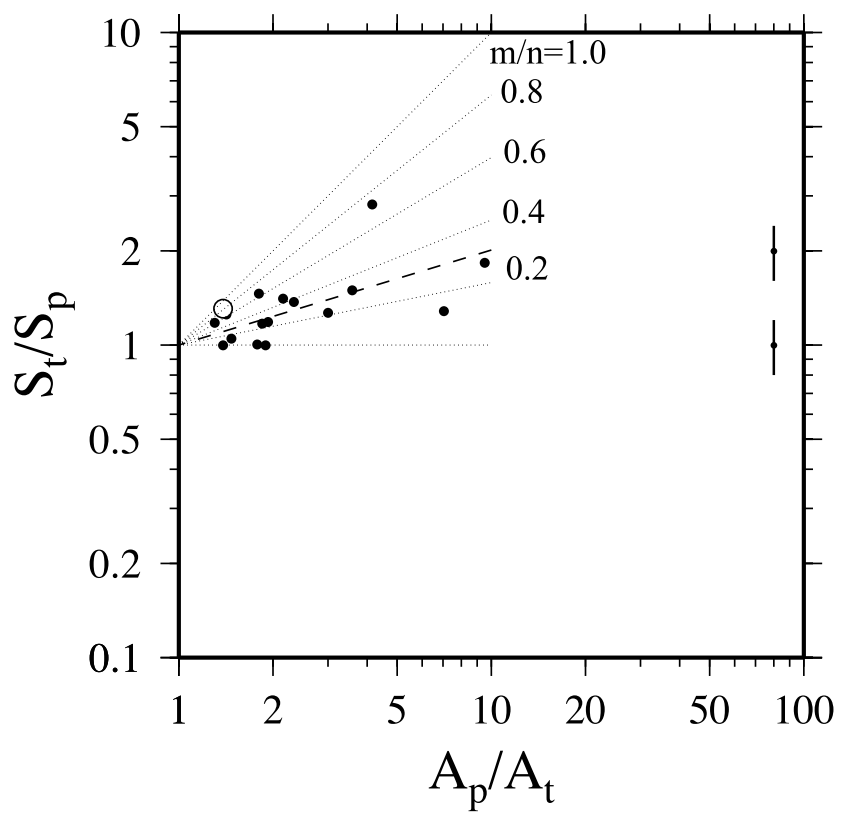

Fig. 7. Ratio of tributary to principal channel gradients against the ratio of hemipelagic catchment areas for (A) canyons that extend from the shelf break and (B) canyons not linked to the shelf. Error bars represent the net uncertainty in $S_{t} / S_{p}$. The data shown with unfilled circles are those data with both $A_{t}$ and $\mathrm{A}_{\mathrm{p}}>5 \mathrm{~km}^{2}$. Oblique dotted lines show the relationship expected with the different values of $\mathrm{m} / \mathrm{n}$ shown. The dashed lines are least-squares regressions constrained to pass through (1,1). In (A) only data with $\mathrm{A}_{t}$ and $A_{p}>5 \mathrm{~km}^{2}$ were used in the regression whereas in (B) the regression was passed through all the data shown. 

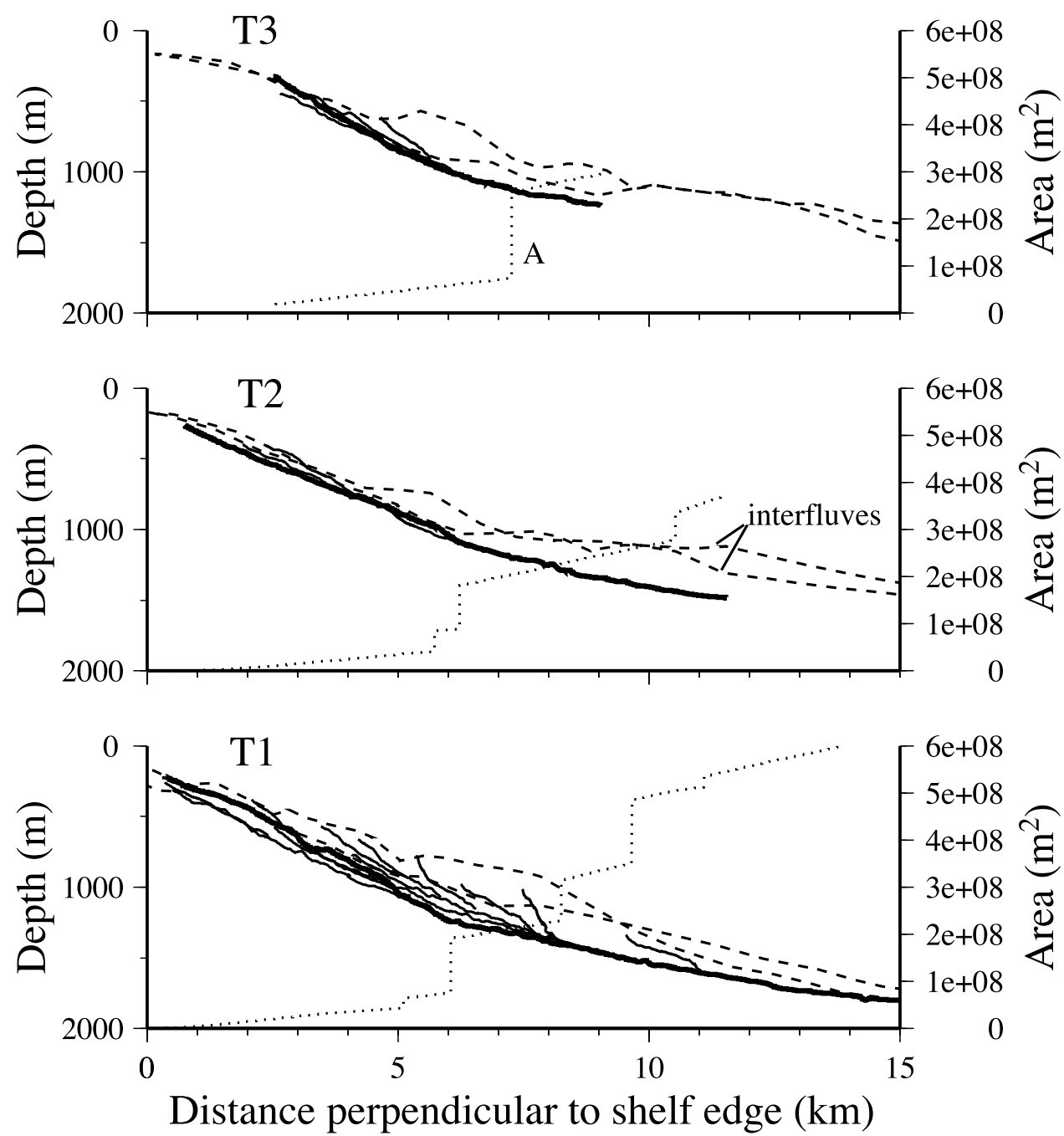

Fig. 8. Longitudinal profiles of three canyons with tributaries are shown. In each graph, the bold line represents the principal channel, finer continuous lines represent tributary channels, dotted line represents the contributing area to the principal channel and dashed lines represent the elevation of the adjacent inter-canyon divides or interfluves. The canyons T1-T3 are located in figure 2.

knickpoints are observed to correlate at common depth between adjacent channels, such as highlighted in figure 9 (occurring along directions oblique to the collecting north-south ship tracks so they are not obviously sonar data artifacts). This view is reinforced in figure 10, which shows that gradients of both large-area and small-area canyons (in effect the most dendritic to least dendritic or linear canyons) decline to common values over a comparable distance from the shelf edge. Increasing induration with depth of strata could have inhibited erosion so that channel beds of the large-area canyons have not evolved to the lowest gradients.

Least-squares regressions were calculated from the data in figure 7 , constrained to pass through $(1,1)$. Because of the difficulty in defining the up-slope limits of the canyons where they head at the shelf edge, the effect of this uncertainty was minimized 


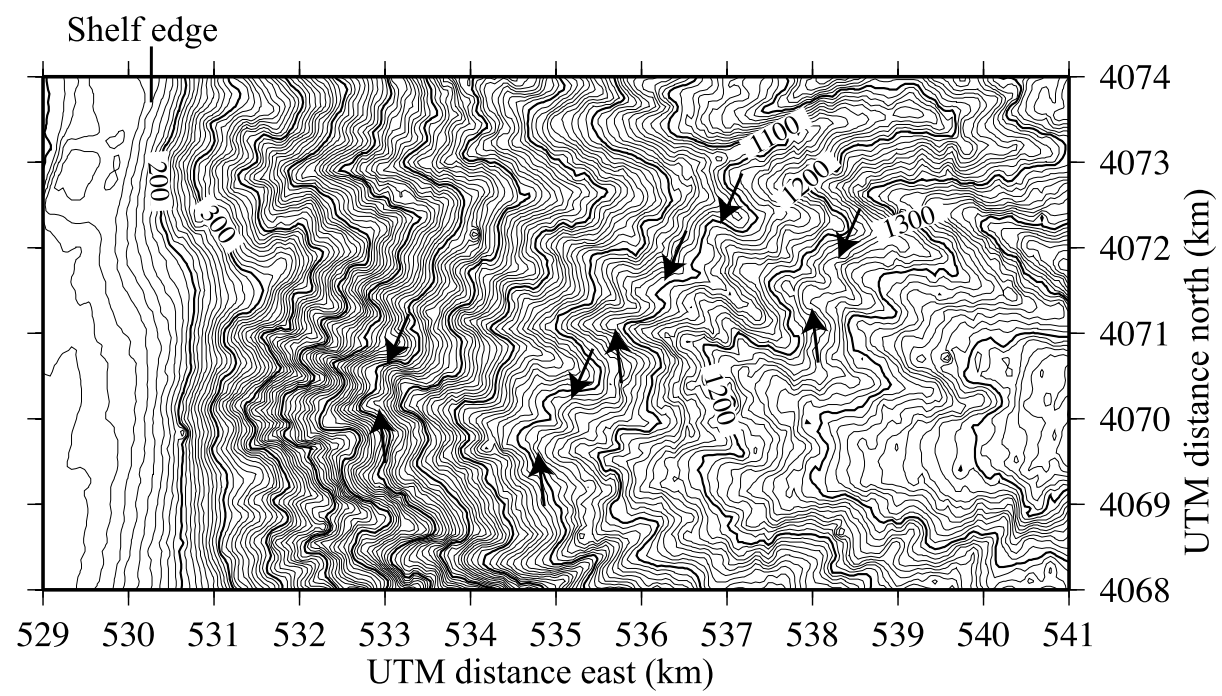

Fig. 9. A section of the multibeam sonar data contoured at $10 \mathrm{~m}$ depth intervals. The arrows highlight areas where variations in down-slope gradient along adjacent channels are coherent at common depth, suggesting a possible lithologic control. Coordinates are Universal Transverse Mercator projection distances in kilometers (UTM zone 18, projection calculated with the WGS84 ellipsoid) and the area is located on figure 2 .

by calculating the regression on the data in figure 7A excluding those with both $\mathrm{A}_{\mathrm{t}}$ and $A_{p}<5 \mathrm{~km}^{2}$, which suggests $\mathrm{m} / \mathrm{n}=0.19$. Regressing all the data shown without this constraint suggests $\mathrm{m} / \mathrm{n}=0.17$. For the data in figure $7 \mathrm{~B}$, the regression was calculated on all the data shown suggesting $\mathrm{m} / \mathrm{n}=0.3$. Regressing on all the data in figures $7 \mathrm{~A}$ and $7 \mathrm{~B}$ combined without censoring suggests $\mathrm{m} / \mathrm{n}=0.19$. The results show that the shelf-heading and slope-heading canyons are similar in terms of gradient-area contrast at confluences.

Regressions were also calculated on the data with areas $A_{t}$ and $A_{p}$ greater than $a$ certain value (fig. 11A) and less than a certain value (fig. 11B). These calculations were used in an attempt to isolate different erosion laws which might, for example, correspond to a change from debris flow to turbidity current erosion with increasing canyon area and declining gradient. Such changes might occur, for example, if debris flows dilute by incorporating ambient water (Mohrig and Marr, 2003). The trend in figure $11 \mathrm{~B}$ is unfortunately not well resolved, as the data for canyons heading at the shelf break were calculated with $\mathrm{A}_{\mathrm{p}} / \mathrm{A}_{\mathrm{t}}$ spanning less than half an order of magnitude where $A_{p}, A_{t}<4 \mathrm{~km}^{2}$ and for the canyons heading within the slope where $A_{p}, A_{t}<5$ $\mathrm{km}^{2}$. Consequently the data in both figures $11 \mathrm{~A}$ and $11 \mathrm{~B}$ suggest $\mathrm{m} / \mathrm{n}=0.2-0.3$ with little evidence for a change with area. The least-squares regressions shown in figures 7A and $7 \mathrm{~B}$ suggest $\mathrm{m} / \mathrm{n}=0.20$ and 0.30 , respectively.

\section{DISCUSSION}

\section{The Analogy Between Submarine and Subaerial Erosion}

The analysis of multibeam echo-sounder data has revealed morphological similarities between these continental slope canyons and subaerial channel systems produced by runoff, which imply similarity of the erosion process. Fluvial-like morphological features of submarine canyons include: (1) inverse power-law relationships between channel gradient and contributing area (fig. 5), reflecting channel long-profile 


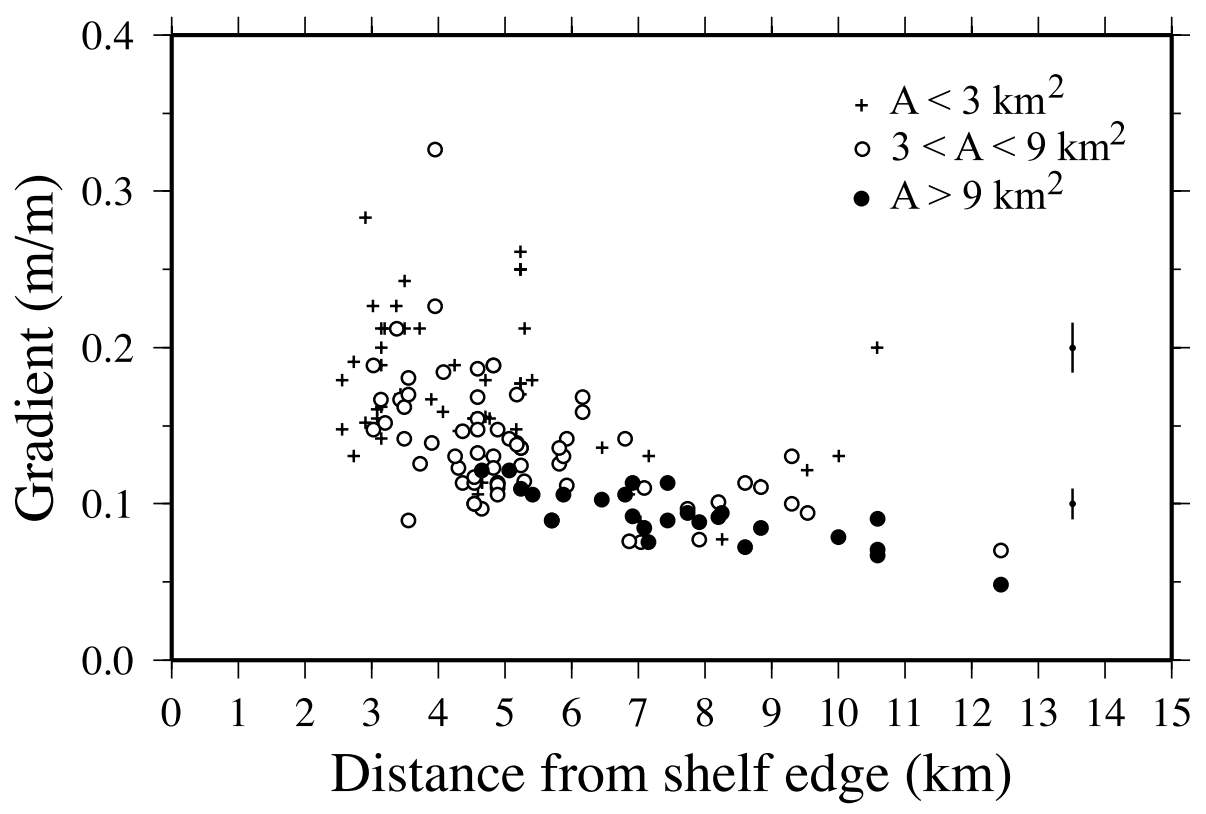

Fig. 10. Gradients of the slope canyon floors plotted versus their distances from the shelf edge, defined as the canyon head contours annotated in figure 2B. The data from canyons draining the southern levee of Norfolk Canyon have been excluded. The symbols represent canyons with area less than $3 \mathrm{~km}^{2}$ (plus symbols), between 3 and $9 \mathrm{~km}^{2}$ (open circles) and greater than $9 \mathrm{~km}^{2}$ (solid circles). For distances beyond 6 $\mathrm{km}$, the channels of the larger tributary networks $\left(A>9 \mathrm{~km}^{2}\right)$ have similar gradients to the more linear canyons with less dendritic structure $\left(\mathrm{A}<3 \mathrm{~km}^{2}\right)$. This is possible evidence that erosion rate is not solely controlled by gradient and contributing area, but that increasing bedrock induration with burial depth may inhibit erosion.

concavity (fig. 8); (2) canyons show Hack's law scaling between channel length and contributing area (Mitchell, unpublished data); (3) tributary branching can be analogous to river systems (Pratson and Ryan, 1996); (4) tributaries approach principal channels at the same elevation, obeying Playfair's Law; and (5) there is a tendency for tributary channels to be steeper than principal channels near confluences, reflecting their smaller contributing areas (fig. 7). Some of these features can be observed visually in the enlarged contour maps (figs. 4 and 9), such as a smooth convergence of channel elevations at confluences. This signature of erosion is more likely to have been created by many small erosive sedimentary flows on the different branches (Malinverno and others, 1988) rather than a small number of large flows, which would have left tributaries forming hanging valleys at confluences.

There are, however, a number of aspects in which the analogy with mature bedrock-eroding streams is imperfect. For example, the tributary channels obey equation (3) in only a very approximate sense, illustrated by the variability of the data in figure 7. From equation (2), some of this variability could originate from variations in thickness and density of turbidity currents arising from their incorporation of channel bed sediments (Parker and others, 1986) affecting parameter G. Some could have arisen from varied bedrock erodibility (varied K) as implied by the knickpoints (figs. 8 and 9) and from the expected increasing induration of slope sediments with burial depth, such as recorded in penetrometer tests on New Jersey slope sediments (Mountain and others, 1994). The role of small debris flows, which form abundant deposits in New Jersey slope cores (McHugh and others, 2002), is uncertain. Their potential to hydroplane (Harbitz and others, 2003) and transform to turbidity currents 


\section{A. Large area canyons}

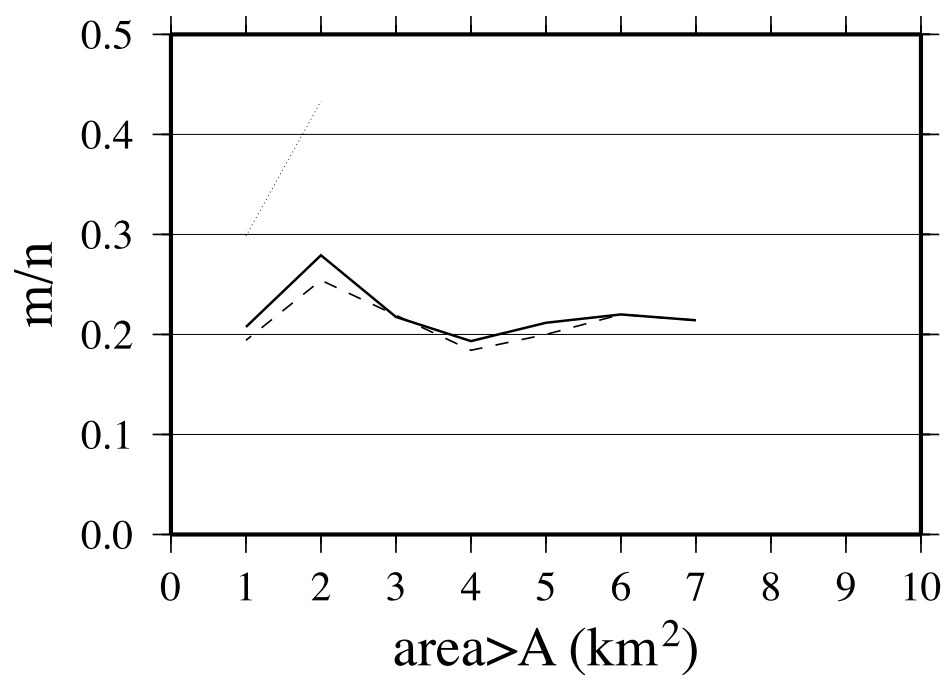

\section{B. Small area canyons}

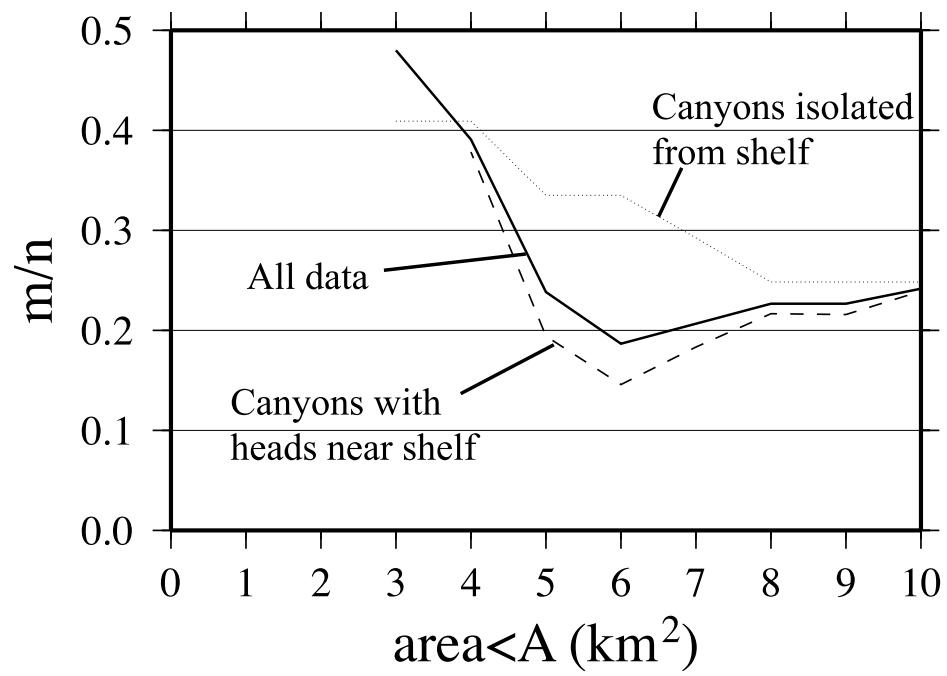

Fig. 11. Gradient of the constrained regressions of figure 7 obtained with progressive censoring of the data according to area. Only regressions with $\mathrm{N}>6$ were used. (A) Regressions with both principal and tributary area greater than A to isolate large canyons. (B) Regressions with both principal and tributary area less than A to isolate small canyons. The lines represent (dotted) only canyons with no heads intersecting the shelf break, (dashed) canyons with heads at the shelf break and (3) all canyon data. The change in (B) for $\mathrm{A}<5 \mathrm{~km}^{2}$ is poorly constrained so both graphs effectively suggest that $\mathrm{m} / \mathrm{n}=0.2-0.3$ for both large and small canyons.

(Mohrig and Marr, 2003) could affect down-stream variations in erosive potential. Furthermore, spatial variations in hemipelagic sediment supply (Sanford and others, 1990; Biscaye and Anderson, 1994), and spatially varied triggers of slope failure such as caused by localized fluid escape (Dugan and Flemings, 2000) could further affect 
down-stream variations in erosion rate. Given the various potential causes of erosion variability, the fact that a fluvial-like geomorphologic signal remains is interpreted here to imply that the processes by which turbidity currents and debris flows erode their beds are indeed likely to be similar to those involved in river bed erosion. It is unlikely that similar morphological characteristics arose from a fortuitous combination of other processes such as large-scale landsliding.

\section{Concavity of Submarine Canyons}

The concavities implied by the data in figure $7(\theta=0.2$ to 0.3$)$ are at the low end of values found in typical river systems, which have $\theta=0.3$ to 0.6 , though within the full range of recorded values, $\theta=0.1$ to 1.1 [from sources cited by Snyder and others (2000) and Tucker and Whipple (2002)]. This range in values could have arisen from a weak sensitivity to area and small $\mathrm{m}$ or from a strong erosion sensitivity to gradient and hence large $n$. For example, river bed erosion by abrasion and by plucking have been predicted to occur with $n=5 / 3$ and with $n=2 / 3$ to 1 , respectively (Whipple and others, 2000), so abrasion-dominated erosion would lead to smaller $\mathrm{m} / \mathrm{n}$ and thus $\theta$. If flows increase their erosive potential by igniting down-stream (Parker and others, 1986) or if decoupled hydroplaning debris flows transform to more erosive turbidity currents downstream (Mohrig and Marr, 2003), however, $\mathrm{m}>1$ would be expected, leading to large $\mathrm{m} / \mathrm{n}$. The fact that $\mathrm{m} / \mathrm{n}$ is small implies that factors leading to $\mathrm{m}<1$ dominate, such as debris flows freezing because of the down-stream decline in gradient, flow widening and increasing induration and resistance to erosion of substrate with burial depth of incised strata.

An effect equivalent to subaerial weathering in preparing bedrock for erosion (Howard, 1998) can be envisaged that could affect canyon concavity $\theta$. On the modern continental slope, biological activity is important in excavating cavities in bedrock and semi-indurated sediment (Dillon and Zimmerman, 1970; Warme and others, 1978; Valentine and others, 1980; Malahoff and others, 1982). Biological activity could cause greater erosion rates in the steeper channel of the upper slope if bedrock were exposed more often there compared with the lower to middle slope, because the latter areas can be protected by superficial hemipelagic sediments and alluvium, accumulated where ocean currents are weaker (Csanady and others, 1988; Cacchione and others, 2002). The strength of biological activity may also reflect the pattern of nutrient input from hemipelagic fallout, which is currently greatest in the upper continental slope (Biscaye and others, 1988; Biscaye and Anderson, 1994). Biological attack could therefore lead to erosion rates being apparently more sensitive to channel gradients than might otherwise be anticipated.

\section{Origin of the Gradient-area Inverse Power-law Relationships and Shelf Spillover Contribution to Canyon Erosion}

In fluvial systems, inverse power-law relationships between channel gradient and contributing area have been interpreted in terms of detachment-limited stream bed erosion laws of the kind $\dot{E} \sim \mathrm{A}^{\mathrm{m}} \mathrm{S}^{\mathrm{n}}$, where tectonic uplift rate is constant and spatially uniform (Whipple and Tucker, 1999) or spatially varied but correlated with A (Kirby and Whipple, 2001). Simulations based on the stream-power erosion laws have also predicted relations of the form $\mathrm{S} \sim \mathrm{A}^{-\theta}$ for declining orogens where significant tectonic activity has long-since ended (Willgoose, 1994), such as the Appalachians (Hack, 1957). Tucker and Whipple (2002) noted that the concavities $\theta$ of declining orogen rivers are very similar to those of tectonically active orogens, so that idealized steady state models can also represent tendencies in declining orogens. The inverse power-law relationship then presumably arises, in terms of the stream-power model, because the fluvial-system erosion rate declines systematically from the range divide to zero at base level. 
Elsewhere (Mitchell, unpublished data) it is argued that continental slopes could evolve towards a form of topographic steady state in which competition between depositing hemipelagic sediment attempting to aggrade the slope is balanced by erosion along channels. In the model, hemipelagic sediments accumulate everywhere on the continental slope attempting to aggrade it. Without erosion, the accumulating sediments would simply prograde the slope. Occasionally a portion of canyon wall will fail, initiating a sedimentary flow that would erode down to the base of the slope (fig. 3). Some parts of the lower canyon walls can be undermined, initiating further slope failures (Pratson and Coakley, 1996; Densmore and others, 1997) and leading the inter-canyon divides to become progressively sharp and angular from landsliding, as is observed (fig. 1). With time, the system would evolve towards a form of steady state between the aggradation and erosion. If aggradation dominates, the slope profile may still be considered a steady state form if measured in a reference frame migrating with the prograding slope and if channel beds also prograde. (On the timescale of a flow event, they will clearly erode but deposition between flows could lead to channels aggrading over longer timescales.) This steady state would be somewhat different to the fluvial case, where erosion is ultimately caused by precipitation, because in the submarine model the hemipelagic sediments both grow the slope and oppose its growth by producing the erosive sedimentary flows.

The supply of hemipelagic sediment to the central Atlantic slope is non-uniform and typically greatest towards the upper slope, as suggested by sediment trap measurements (Biscaye and others, 1988; Biscaye and Anderson, 1994) and sedimentation rates from cores (Sanford and others, 1990). However, as the channel gradient and area data here were mostly derived from within $15 \mathrm{~km}$ of the shelf edge (fig. 10), the hemipelagic rain can be assumed to have a spatially uniform long-term value $\mathrm{U}$. If the channel bed erosion has become balanced with the accumulation, then:

$$
\mathrm{U}=\mathrm{KA}^{\mathrm{m}} \mathrm{G}^{\mathrm{n}} \mathrm{S}^{\mathrm{n}}
$$

and an inverse power-law relation $S \sim A^{-\theta}$ with $\theta=m / n$ is expected if $G, K, m$ and $n$ are spatially uniform and constant. As before, some down-stream variation in these parameters is likely to cause the concavity $\theta$ to differ from $\mathrm{m} / \mathrm{n}$.

The steady state model can be used to constrain the amount of shelf spillover as follows. The supply of sediment direct to canyon heads is represented by increasing canyon contributing areas by an amount $\delta$, which effectively represents the volumetric flux of shelf sediment to a canyon head. From equation (2), the effect of spillover can then be written $\dot{E}=\mathrm{kG}^{\mathrm{n}}(\mathrm{A}(1+\delta))^{\mathrm{m}} \mathrm{S}^{\mathrm{n}}$. For a steady-state landscape, $\mathrm{U}=\mathrm{kG}^{\mathrm{n}}(\mathrm{A}(1+$

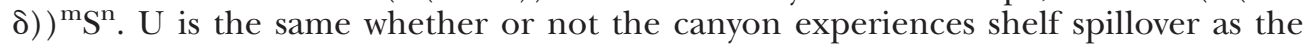
spillover sediment travels down the channel without depositing, bypassing the slope. If hemipelagic deposition was enhanced during times of lowered sea level (Vail and others, 1977), U varies with time, but it should have the same value for both shelf-heading and slope-heading canyons. Gradient is given by $\mathrm{S}=(\mathrm{U} / \mathrm{K})^{1 / \mathrm{n}} \mathrm{G}^{-1}(\mathrm{~A}+$ $\delta)^{-m / n}$. Finding the difference in $\log _{10}(\mathrm{~A})$ for a given $\mathrm{S}$ between the two graphs in figure 5 should resolve $\delta$, if the other factors are common. The difference is statistically unresolved, but we can instead find the maximum possible $\delta$ allowed by the uncertainties. From the separation of the maximum uncertainty curve in the figure $5 \mathrm{~A}$ regression to the minimum uncertainty curve of the figure $5 \mathrm{~B}$ regression at around $\log _{10}(\mathrm{~A})=6.5\left(\mathrm{~A}=3.2 \mathrm{~km}^{2}\right)$, it was deduced that $\delta=1.05$, an extreme estimate as the uncertainties are not correlated. Thus an amount of shelf spillover no more than equal to the hemipelagic volume flux to a canyon area of $3.2 \mathrm{~km}^{2}$ has contributed to canyon erosion according to this argument. If shelf spillover consists of turbidity currents of shelf sand and gravels that are more erosive than those formed of semi-indurated sediment of canyon wall failures, these volumetric contributions are over-estimated. 


\section{CONCLUSIONS}

The central Atlantic USA continental slope canyons have many features in common with subaerial drainage systems, such as inverse power-law relationship between channel gradient and contributing area with concavity $\theta=0.3$, tributaries join at confluences smoothly with the same elevation (not forming hanging valleys) and there is a tendency for tributaries with small contributing areas to have steeper channels than the principal channels that they join. A simple model for bed erosion by turbidity currents based on the detachment-limited bed shear stress model (Howard, 1994) illustrates how a similar erosional morphology to that in fluvial systems could arise and illustrates some potential sources of complexity. In river networks, discharge increases systematically down-stream, but tributaries in submarine canyon systems are not usually simultaneously active. A tendency for erosion rates to increase down-stream instead arises from increasing frequency and size of sedimentary flows incising the canyon floor, which relate to the up-stream area of canyon walls accumulating unstable sediment deposits. Erosion in the continental slope has progressed towards a form of spatial equilibrium so that channels have concave-upwards long-profiles, with the down-stream effect of increasing flow frequency balanced by decreasing gradient.

There is, however, more significant variability in graphs of gradient and area ratio at confluences than those presented by Seidl and Dietrich (1992). Some potential sources of variability include (1) changing power of flows down-stream as they incorporate bed material (Parker and others, 1986), (2) varied induration of incised strata, (3) variations in dominant flow type (turbidity currents and debris flows), (4) freezing of debris flows with declining gradient, (5) transformation of debris flows to turbidity currents (Mohrig and Marr, 2003) and (6) spatially varied hemipelagic sediment deposition (Biscaye and Anderson, 1994) or varied trigger of slope failure such as fluid release (Dugan and Flemings, 2000). In addition, causes of erosional variability suggested for river systems will also apply, such as effects of varied sediment load (Sklar and Dietrich, 1998). The varied resistance to erosion is implied by correlated knickpoints observed between adjacent channels. The channels of both small and large area canyons should decline in gradient over a different distance from the shelf edge because of the different cumulative volumes of sedimentary flows they have experienced, but they are observed to decline over a similar distance. This could be a result of increasing induration with burial depth inhibiting deeper erosion.

Although there are various potential causes of variability, a fluvial-like signal remains. This is interpreted here to indicate that the fundamental erosion process likely does involve plucking/quarrying and abrasion of the bed by sedimentary flows in an analogous manner to erosion by runoff on land (Hancock and others, 1998; Whipple and others, 2000). A process of large-scale slope failure carving these canyons is unlikely to have produced fluvial-like characteristics fortuitously.

A prediction of the classical sequence stratigraphic model is that sediment supply to slopes and canyon erosion are more enhanced during sea-level lowstands (Vail and others, 1977). The power-law relationships and graphs of gradient and area ratio at tributaries, however, are not greatly different for slope canyons that head near the shelf break compared with those that head within the continental slope. If sediment were supplied directly to canyon heads during low-stands and enhanced erosion, the shelf break-heading canyons would be expected to have evolved to different gradients for a given contributing area, but this is not observed, neither is there evidence for feeding channels at the shelf edge. Therefore any enhanced erosion activity, if it occurred, must have been caused by enhanced hemipelagic supply to all canyons.

The National Geophysical Data Center of NOAA supplied the multibeam sonar data used in this study. Brian Dade is thanked for helpful insight and inspiration, which 
started the author's work on slope erosion. Lesli Wood, Noah Snyder, and an anonymous associate editor are thanked for their constructive and helpful reviews. Figures in this paper were produced with the GMT software system (Wessel and Smith, 1991). This research was supported by a research fellowship from the Royal Society.

\section{REFERENCES}

Adams, J., 1990, Paleoseismicity of the Cascadia subduction zone: Evidence from turbidites off OregonWashington margin: Tectonophysics, v. 9, p. 569-583.

Alonso, B., Kastens, K. A., Maldonado, A., Malinverno, A., Hans Nelso, C., O’Connell, S., Palangues, A., and Ryan, W. B. F., 1985, Morphology of the Ebro Fan valleys from SeaMARC and Sea Beam profiles: Geomarine Letters, v. 5, p. 141-148.

Armishaw, J. E., Holmes, R. W., and Stow, D. A. V., 2000, The Barra Fan: A bottom-current reworked, glacially-fed submarine fan system: Marine and Petroleum Geology, v. 17, p. 219-238.

Bagnold, R. A., 1963, Mechanics of marine sedimentation, in Hill, M. N., editor, The Sea, v. 3: New York, Interscience, p. 507-528.

Biscaye, P. E., and Anderson, R. F., 1994, Fluxes of particulate matter on the slope of the southern Middle Atlantic Bight: SEEP-II: Deep-Sea Research, v. 41, p. 459-509.

Biscaye, P. E., Anderson, R. F., and Deck, B. L., 1988, Fluxes of particles and constituents to the eastern United States continental slope and rise: SEEP-I: Continental Shelf Research, v. 8, p. 855-904.

Burbank, D. W., and Anderson, R. S., 2000, Tectonic Geomorphology: Malden, Massachusetts, Blackwell, $288 \mathrm{p}$.

Cacchione, D. A., Pratson, L. F., and Ogston, A. S., 2002, The shaping of continental slopes by internal tides: Science, v. 296, p. 724-727.

Csanady, G. T., Churchill, J. H., and Butman, B., 1988, Near-bottom currents over the continental slope in the Mid-Atlantic Bight: Continental Shelf Research, v. 8, p. 653-671.

Daly, R. A., 1936, Origin of submarine "canyons": American Journal of Science, v. 231, p. 401-420.

Densmore, A. L., Anderson, R. S., McAdoo, B. G., and Ellis, M. A., 1997, Hillslope evolution by bedrock landslides: Science, v. 275, p. 369-372.

Dillon, W. P., and Zimmerman, H. B., 1970, Erosion by biological activity in two New England submarine canyons: Journal of Sedimentary Petrolology, v. 40, p. 542-547.

Dowdeswell, J. A., Ó Cofaigh, C., Taylor, J., Kenyon, N. H., Mienert, J., and Wilken, M., 2002, On the architecture of high-latitude continental margins: the influence of ice-sheet and sea-ice processes in the Polar North Atlantic, in Dowdeswell, J. A., and Ó Cofaigh, C., editors, Glacier-influenced sedimentation on high-latitude continental margins: Geological Society of London Special Publication 203, p. 33-54.

Dowdeswell, J. A., Ó Cofaigh, C., and Pudsey, C. J., 2004, Continental slope morphology and sedimentary processes at the mouth of an Antarctic palaeo-ice stream: Marine Geology, v. 204, p. 203-214.

Doyle, L. J., Pilkey, O. H., and Woo, C. C., 1979, Sedimentation on the eastern United States continental slope, in Doyle, L. J., and Pilkey, O. H., editors, Geology of continental slopes: Tulsa, Oklahoma, Society Economic Paleontologist Mineralogist, p. 119-129.

Dugan, B., and Flemings, P. W., 2000, Overpressure and fluid flow in the New Jersey continental slope: Implications for slope failure and cold seeps: Science, v. 289, p. 288-291.

Dugan, B., Flemings, P. W., Olgaard, D. L., and Gooch, M. J., 2003, Consolidation, effective stress, and fluid pressure of sediments from ODP Site 1073, US mid-Atlantic continental slope: Earth and Planetary Science Letters, v. 215, p. 13-26.

EEZ Scan, 1991, Atlas of the U.S. Exclusive Economic Zone, Atlantic continental margin: U.S. Geological Survey Miscellaneous Investigations Series I-2054, $174 \mathrm{p}$.

Farre, J. A., 1987, Surficial geology of the continental margin offshore New Jersey in the vicinity of Deep Sea Drilling Project Sites 612 and 613, in Poag, C. W., and Watts, A. B., editors, Initial Reports of Deep Sea Drilling Project, v. 95: Washington, D.C., United States Government Printing Office, p. 725-759.

Forde, E. B., 1981, Evolution of Veatch, Washington and Norfolk submarine canyons: inferences from strata and morphology: Marine Geology, v. 39, p. 197-214.

Goff, J. A., Swift, D. J. P., Duncan, C. S., Mayer, L. A., and Hughes Clarke, J. E., 1999, High-resolution swath sonar investigations of sand ridge, dune and ribbon morphology in the offshore environment of the New Jersey margin: Marine Geology, v. 161, p. 307-337.

Goldfinger, C., Nelson, C. H., and Johnson, J. E., 2003, Holocene earthquake records from the Cascadia subduction zone and northern San Andreas Fault based on precise dating of offshore turbidites: Annual Reviews of Earth and Planetary Science, v. 31, p. 555-577.

Hack, J. T., 1957, Studies of longitudinal stream profiles in Virginia and Maryland: Washington, United States Government Printing Office, p. 42-97.

Hancock, G. S., Anderson, R. S., and Whipple, K. X., 1998, Beyond power: Bedrock river incision process and form, in Tinkler, K. J., and Wohl, E. E., editors, Rivers over rock: Fluvial processes in bedrock channels: Washington, D.C., American Geophysical Union, p. 35-60.

Harbitz, C. B., Parker, G., Elverhoi, A., Marr, J. G., Mohrig, D., and Harff, P. A., 2003, Hydroplaning of subaqueous debris flows and glide blocks: Analytical solutions and discussion: Journal of Geophysical Research, v. 108, p. doi:10.1029/2001JB001454.

Howard, A. D., 1994, A detachment-limited model of drainage basin evolution: Water Resources Research, v. 30 , p. 2261-2285.

1998, Long profile development of bedrock channels: Interaction of weathering, mass wasting, bed 
erosion, and sediment transport, in Tinkler, K. J., and Wohl, E. E., editors, Rivers over rock: Fluvial processes in bedrock channels: Washington, D. C., American Geophysical Union, p. 297-319.

Kirby, E., and Whipple, K., 2001, Quantifying differential rock-uplift rates via stream profile analysis: Geology, v. 29, p. 415-418.

Klaucke, I., and Cochonat, P., 1999, Analysis of past seafloor failures on the continental slope off Nice (SE France): Geo-Marine Letters, v. 19, p. 245-253.

Komar, P. D., 1969, The channelized flow of turbidity currents with applications to Monterey deep-sea fan channel: Journal of Geophysical Research, v. 74, p. 4544-4558.

1977, Computer simulation of turbidity current flow and the study of deep-sea channels and fan sedimentation, in Goldberg, E. D., McCave, I. N., O'Brien, J. J., and Steele, J. H., editors, The Sea: Ideas and Observations on Progress in the Study of the Seas: New York, John Wiley and Sons, p. 603-621.

Malahoff, A., Embley, R. W., and Fornari, D. J., 1982, Geomorphology of Norfolk and Washington Canyons and the surrounding continental slope and upper rise as observed with DSRV Alvin, in Scrutton, R. A., and Talwani, M., editors, The Ocean Floor: New York, John Wiley and Sons, p. 97-111.

Malinverno, A., Ryan, W. B. F., Auffret, G. A., and Pautot, G., 1988, Sonar images of recent failure events on the continental margin off Nice, France: Geological Society of America Special Paper 229, p. 59-75.

McGregor, B. A., and Bennett, R. H., 1977, Continental slope sediment instability northeast of Wilmington Canyon: American Association Petroleum Geologists Bulletin, v. 61, p. 918-928.

McGregor, B. A., Bennett, R. H., and Lambert, D. N., 1979, Bottom processes, morphology and geotechnical properties of the continental slope south of Baltimore Canyon: Applied Ocean Research, v. 1, p. 177-187.

McGregor, B. A., Stubblefield, W. L., Ryan, W. B. F., and Twichell, D. C., 1982, Wilmington submarine canyon: a marine fluvial-like system: Geology, v. 10, p. 27-30.

McHugh, C. M., Ryan, W. B. F., and Schreiber, B. C., 1993, The role of diagenesis in exfoliation of submarine canyons: American Association Petroleum Geologists, v. 77, p. 145-172.

McHugh, C. M. G., and Olson, H. C., 2002, Pleistocene chronology of continental margin sedimentation: New insights into traditional models, New Jersey: Marine Geology, v. 186, p. 389-411.

McHugh, C. M. G., Damuth, J. E., and Mountain, G. S., 2002, Cenozoic mass-transport facies and their correlation with relative sea-level change, New Jersey continental margin: Marine Geology, v. 184, p. 295-334.

Miller, J. R., 1991, The influence of bedrock geology on knickpoint development and channel-bed degradation along downcutting streams in south-central Indiana: Journal of Geology, v. 99, p. 591-605.

Mitchell, N. C., 1993, A model for attenuation of backscatter due to sediment accumulations and its application to determine sediment thickness with GLORIA sidescan sonar: Journal of Geophysical Research, v. 98, p. 22477-22493.

Mohrig, D., and Marr, J. G., 2003, Constraining the efficiency of turbidity current generation from submarine debris flows and slides using laboratory experiments: Marine and Petroleum Geology, v. 20, p. 883-899.

Montgomery, D. R., and Gran, K. B., 2001, Downstream variations in the width of bedrock channels: Water Resources Research, v. 37, p. 1841-1846.

Mountain, G. S., Miller, K. G., and Blum, P., 1994, Proceedings of the Ocean Drilling Program Initial Reports, 150, v. 150: Austin, Texas, Ocean Drilling Program.

Niemann, J. D., Gasparini, N. M., Tucker, G. E., and Bras, R. L., 2001, A quantitative evaluation of Playfair's law and its use in testing long-term stream erosion laws: Earth Surface Processes and Landforms, v. 26, p. 1317-1332.

Parker, G., Fukushima, Y., and Pantin, H. M., 1986, Self-accelerating turbidity currents: Journal of Fluid Mechanics, v. 171, p. 145-181.

Peakall, J., McCaffrey, W., and Kneller, B., 2000, A process model for the evolution, morphology, and architecture of sinuous submarine channels: Journal of Sedimentary Research, v. 70, p. 434-448.

Piper, D. J. W., Shor, A. N., and Hughes Clarke, J. E., 1988, The 1929 "Grand Banks" earthquake, slump and turbidity current, in Clifton, H. E., editor, Sedimentological Consequences of Convulsive Geologic Events: Boulder, Geological Society of America Special Paper 229, p. 77-92.

Piper, D. J. W., Cochionat, P., and Morrison, M. L., 1999, The sequence of events around the epicentre of the 1929 Grand Banks earthquake: Initiation of debris flows and turbidity current inferred from sidescan sonar: Sedimentology, v. 46, p. 79-97.

Playfair, J., 1802, Illustrations of the Huttonian Theory of the Earth: London, Dover, 528 p.

Pratson, L. F., 2001, A perspective on what is known and not known about seafloor instability in the context of continental margin evolution: Marine and Petroleum Geology, v. 18, p. 499-501.

Pratson, L. F., and Coakley, B. J., 1996, A model for the headward erosion of submarine canyons induced by downslope-eroding sediment flows: Geological Society of America Bulletin, v. 108, p. 225-234.

Pratson, L. F., and Haxby, W. F., 1997, Panoramas of the seafloor: Scientific American, v. 276, p. 66-71.

Pratson, L. F., and Laine, E. P., 1989, The relative importance of gravity-induced versus current-controlled sedimentation during the Quaternary along the Mideast U.S. outer continental margin revealed by 3.5 kHz echo character: Marine Geology, v. 89, p. 87-126.

Pratson, L. F., and Ryan, W. B. F., 1996, Automated drainage extraction for mapping the Monterey submarine drainage system, California margin: Marine Geophysical Research, v. 18, p. 757-777.

Pratson, L. F., Ryan, W. B. F., Mountain, G. S., and Twichell, D. C., 1994, Submarine canyon initiation by downslope-eroding sediment flows: Evidence in late Cenozoic strata on the New Jersey continental slope: Geological Society of America Bulletin, v. 106, p. 395-412.

Roe, G. H., Montgomery, D. R., and Hallet, B., 2002, Effects of orographic precipitation on the concavity of steady-state river profiles: Geology, v. 30, p. 143-146. 
Sanford, M. W., Kuehl, S. A., and Nittrouer, C. A., 1990, Modern sedimentary processes in the Wilmington Canyon area, United States east coast: Marine Geology, v. 92, p. 205-226.

Schlee, J. S., and Robb, J. M., 1991, Submarine processes of the middle Atlantic continental rise based on GLORIA imagery: Geological Society of America Bulletin, v. 103, p. 1090-1103.

Schlee, J. S., Dillon, W. P., and Grow, J. A., 1979, Structure of the continental slope off the Eastern United States, in Doyle, L. J., and Pilkey, O. H., editors, Geology of continental slopes: Tulsa, Oklahoma, Society of Economic Paleontologists and Mineralogists, p. 95-117.

Seidl, M., and Dietrich, W. E., 1992, The problem of channel erosion into bedrock: Catena Supplement, v. 23, p. 101-124.

Shepard, F. P., 1981, Submarine canyons: multiple causes and long-time persistence: Bulletin of American Association of Petroleum Geologists, v. 65, p. 1062-1077.

Shepard, F. P., Curray, J. R., Inman, D. L., Murray, E. A., Winterer, E. L., and Dill, R. F., 1964, Submarine geology by diving saucer: Science, v. 145, p. 1042-1046.

Sklar, L., and Dietrich, W. E., 1998, River longitudinal profiles and bedrock incision models: Stream power and influence of sediment supply, in Tinkler, K. J., and Wohl, E. E., editors, Rivers over rock: Fluvial processes in bedrock channels: Washington, D.C., American Geophysical Union, p. 237-260. 2001, Sediment and rock strength controls on river incision into bedrock: Geology, v. 29, p. 1087 1090.

Snyder, N. P., Whipple, K. X., Tucker, G. E., and Merritts, D. J., 2000, Landscape response to tectonic forcing: Digital elevation model analysis of stream profiles in the Mendocino triple junction region, northern California: Geological Society of America Bulletin, v. 112, p. 1250-1263.

2003, Importance of a stochastic distribution of floods and erosion thresholds in the bedrock river incision problem: Journal of Geophysical Research, v. 108, p. doi: 10.1029/2001JB001655.

Sommerfield, C. K., and Lee, H. J., 2004, Across-shelf sediment transport since the Last Glacial Maximum, southern California margin: Geology, v. 32, p. 345-348.

Tucker, G. E., and Whipple, K. X., 2002, Topographic outcomes predicted by stream erosion models: Sensitivity analysis and intermodel comparison: Journal of Geophysical Research, v. 107, p. doi: 10.1029/ 2001JB000162.

Vail, P. R., Mitchum, R. M., and Thompson, S., 1977, Seismic stratigraphy and global changes of sea level; Part 4, Global cycles of relative changes of sea level, in Payton, C. E., editor, Memoir: American Association of Petroleum Geologists, p. 83-97.

Valentine, P. C., Uzmann, J. R., and Cooper, R. A., 1980, Geologic and biologic observations in Oceanographer submarine canyon: Descriptions of dives aboard the research submersibles Alvin $(1967,1978)$ and Nekton Gamma (1974): U.S. Geological Survey Open File Report, v. 80-76, p. 40 p.

Warme, J. E., Slater, R. A., and Cooper, R. A., 1978, Bioerosion in submarine canyons, in Stanley, D. J., and Kelling, G., editors, Sedimentation in submarine canyons, fans, and trenches: Stroudsburg, Dowden, Hutchinson and Ross, p. 65-70.

Wessel, P., and Smith, W. H. F., 1991, Free software helps map and display data: EOS Transactions of the American Geophysical Union, v. 72, p. 441.

Whipple, K. X., and Tucker, G. E., 1999, Dynamics of the stream-power river incision model: Implications of height limits of mountain ranges, landscape response timescales, and research needs: Journal of Geophysical Research, v. 104, p. 17661-17674.

2002, Implications of sediment-flux-dependent river incision models for landscape evolution: Journal of Geophysical Research, v. 107, p. doi: 10.1029/2000JB000044.

Whipple, K. X., Hancock, G. S., and Anderson, R. S., 2000, River incision into bedrock: Mechanics and relative efficacy of plucking, abrasion, and cavitation: Geological Society of America Bulletin, v. 112, p. $490-503$.

Willgoose, G., 1994, A physical explanation for an observed area-slope-elevation relationship for catchments with declining relief: Water Resources Research, v. 30, p. 151-159. 